\title{
Editorial
}

\section{El futuro de las revistas de ciencias económicas en Colombia}

http://dx.doi.org/10.14718/revfinanzpolitecon.2015.7.2.1

\section{Joan Miguel Tejedor Estupiñán*}

El 27 de enero del 2015, el Índice Bibliográfico Nacional (IBN Publindex) divulgó el listado de revistas indexadas en la primera actualización del 2014, en el que se reconocen 542 publicaciones científicas editadas por diferentes instituciones, en su mayoría de educación superior, investigación y desarrollo en Colombia. Encontramos allí 28 revistas en categoría A1, 138 en A2, 131 en B y 245 en C (Colciencias, 2015), y ello es muestra de un avance significativo de estas publicaciones en comparación con las 515 revistas indexadas en 2013, y mucho más sí lo confrontamos con las 91 revistas indexadas en 2002, cuando apenas una revista estaba en la categoría A1, 9 revistas en la categoría A2, 7 en la categoría B y 74 en la categoría C (Rodríguez, Naranjo y González, 2015).

En la última actualización de Publindex se reconocieron 67 revistas relacionadas con las ciencias económicas y administrativas colombianas - un 12,4\% del total de revistas indexadas nacionales-, dentro de las cuales 2 se ubicaron en la categoría A1, 21 en A2, 11 en B y 33 en C. Según las condiciones de indexación del IBN, en especial las revistas que se encuentran en las categorías A1 y A2 estarían cumpliendo con la mayoría de requisitos establecidos por pares internacionales en relación con calidad editorial, calidad científica, visibilidad e impacto. De hecho, esto se evidencia cuando encontramos que de estas revistas, aproximadamente 20 se encuentran en EconLit, 24 en RedALyC, 24 en SciELO, 13 en Scopus y 4 en ISI (Tomson Scientific). Queda claro así que poco más de la tercera parte de la producción colombiana en ciencias económicas ha sobrepasado la frontera nacional, con lo cual se aumenta la visibilidad y divulgación internacional y se consolidan procesos de reconocimiento del impacto de los documentos que allí se publican.

Parte de la importancia de estos datos puede analizarse desde su relación con diferentes contextos. Además, ello debe llevar a la comunidad científica nacional a asumir varios debates de gran trascendencia tanto para la política nacional de investigación y desarrollo como para la política laboral de los docentes universitarios en Colombia, que tienen una directa relación con este contexto.

El primer debate se da en el marco de la postura mundial del acceso abierto al conocimiento científico (Budapest Open Access Initiative [BOAl], 2012), que lleva más de 13 años impulsando iniciativas de este tipo, por cuanto constituyen una postura frente al conocimiento como un bien común o un derecho humano universal (encontramos allí propuestas como DOAJ, SciELO y RedALyC). Se contraponen a ellas las bases bibliográficas internacionales impulsadas por los países de la llamada "gran corriente de la ciencia" (donde encontramos a ISI-WOS y Scopus, que son reconocidas en las normatividades nacionales

* Magíster en Derechos Humanos y economista. Editor de la Revista Finanzas y Política Económica de la Universidad Católica de Colombia. Correo electrónico: jmtejedor@ucatolica.edu.co. Dirección de correspondencia: Facultad de Ciencias Económicas y Administrativas, Universidad Católica de Colombia, carrera 13 N. 47-49 (Bogotá, Colombia). 
para conceptos del régimen salarial de los docentes universitarios). Esta últimas bases cobran por la suscripción y el acceso a sus contenidos, y además evidencian la escasa participación de la producción científica latinoamericana e imponen restricciones para poder acceder en estas bases bibliográficas; con ello alejan de manera directa la participación de la producción científica latinoamericana en esta corriente y limitan de la misma forma su visibilidad e impacto (Aguado y Rogel, 2006).

El segundo debate surge luego del proceso desarrollado por Publindex desde el 2012 y hasta la actualidad, cuyo propósito era consolidarse como el sistema nacional de referencia para la evaluación de publicaciones científicas colombianas. Este sistema ha contribuido de manera directa a impulsar gran parte de las publicaciones científicas nacionales en el ámbito internacional; sin embargo, no ha sido ajeno a las críticas desde diferentes perspectivas. Esta coyuntura condujo, por ejemplo, a que para la última medición de grupos de Colciencias, esta institución decidiera no tener en cuenta los resultados del IBN de Publindex; argumentando que el Decreto 1279 de 2002, por el cual se establece el régimen salarial y prestacional de los docentes de las universidades estatales, desde su artículo 10 ha generado dos problemas fundamentales: se ha afectado la calidad de la investigación y la academia en Colombia, así como el mercado laboral de los docentes universitarios. Estos manifiestan el incremento poco significativo de la formación posgraduada, que fue del 9,9\% entre el 2003 y el 2013, frente al aumento de la productividad científica de los docentes universitarios, que aumentó en un $64,3 \%$ en la misma época (Arango, 2009).

En este orden de ideas cabe destacar la desigualdad entre las relaciones laborales de los docentes universitarios de los países desarrollados frente a los países en vía de desarrollo como Colombia, donde un docente puede ganar por hora entre U\$11 y U\$74 (El Observatorio de la Universidad Colombiana, 2014), frente a los U $\$ 100$ por hora que puede ganar un docente con doctorado en países como Alemania y Reino Unido (Arias, 2014).

Finalmente, uno de los debates más importantes tiene que ver con los recursos destinados por el gobierno nacional para el sector estratégico de investigación y desarrollo (I+D). Hay una evidente desigualdad en los términos de competencia generados por las naciones desarrolladas, las cuales hacia 2012 invertían en este sector alrededor de 400.000 millones de dólares en Estados Unidos, 300.000 en la Unión Europea, 150.000 en China y 130.000 en Japón (Banco Mundial, 2012). En contraste, en Colombia la inversión en actividades de ciencia, tecnología e innovación apenas superan los 1757 millones de dólares, y la inversión en I+D apenas supera los 738 millones de dólares (Observatorio Colombiano de Ciencia y Tecnología [OCyT], 2014).

Este panorama deja ver los diferentes retos que hoy más que nunca debemos emprender los equipos editoriales de las publicaciones científicas, que asumimos garantizar la alta calidad científica y editorial de las revistas que lideramos dentro de las instituciones que las respaldan. Así, en un contexto en el que la ciencia y el conocimiento no son ajenos al proceso multidimensional llamado globalización, debemos plantearnos inquietudes como estas: ¿cuáles deben ser los principios de la política de I+D y de ciencia y tecnología en Colombia?, ¿quiénes son los actores que deben participar en la construcción de estas políticas?, ¿cuál es el nivel de recursos económicos, humanos y físicos que debe invertir un 
país y sus instituciones de investigación y desarrollo con miras a alcanzar los estándares de los países desarrollados en esta materia?, ¿cuáles son las políticas y los instrumentos que garantizarían la efectividad y eficiencia de estos recursos? Estas y muchas otras inquietudes están llamadas a ser resueltas de manera política desde comunidades que conforman las instituciones de investigación y desarrollo en Colombia, con el fin de garantizar un futuro sustentable y sostenible para la I+D en Colombia.

Conscientes de este compromiso, así como de nuestra responsabilidad frente a la calidad científica y editorial y del impacto de las investigaciones que publicamos, el equipo editorial de la Revista Finanzas y Política Económica presenta a sus lectores esta nueva edición, en la que buscamos publicar investigaciones reconocidas por su alto impacto. Encontramos así siete artículos de investigación: "El papel del desarrollo financiero como fuente del crecimiento económico", de José Luis Hernández Mota, de la Universidad Autónoma Metropolitana-Azcapotzalco, de México; luego, "El ciclo de dependencia centro-periferia en Argentina", de Luciano Rezzoagli y Guillermina Gamberg, de la Universidad Nacional del Litoral, Santa Fe, Argentina; enseguida, el artículo "Gestión y valor económico del recurso hídrico", de William Gilberto Delgado Munevar, de la Universidad Católica de Colombia; más adelante, "The role of the sub-national public sector in the stabilization function: Evidence from the Colombian case in the period 1990-2000", escrito por Ligia Melo Becerra, del Banco de la República de Colombia; continuamos con "Why does Colombia lack agricultural commodity futures?", de Pablo Moreno Alemay y Catherine Pereira Villa, de la Universidad de La Sabana, Colombia; enseguida, "Análisis comparativo de eficiencia entre Brasil, México y Estados Unidos", escrito por Juan Benjamín Duarte Duarte, Katherine Julieth Sierra Suárez y Víctor Alfonso Rueda Ortiz, de la Universidad Industrial de Santander, Colombia; y para finalizar esta sección, el texto "Determinantes de la estructura de capital de las mipymes del sector real participantes del Premio Innova 2007-2011", de Ana Milena Padilla Ospina, Jorge Alberto Rivera Godoy y Javier Humberto Ospina Holguín, de la Universidad del Valle, Colombia. Finalmente encontramos el artículo de revisión "Posturas de política monetaria ante fluctuaciones de la economía: una revisión de la evolución teórica", de José Mauricio Gil León, de la Universidad Pedagógica y Tecnológica de Colombia.

\section{REFERENCIAS}

Aguado López, E. y Rogel Salazar, R. (2006). Redalyc: Red de Revistas Científicas de América Latina, el Caribe, España y Portugal. Un balance a tres años de camino. En D. Babini y J. Fraga (Eds.), CLACSO, Consejo Latinoamericano de Ciencias Sociales (pp. 209-233). Buenos Aires: CLACSO. Recuperado de http://bibliotecavirtual.clacso.org.ar/ar/libros/secret/babini/Aguado Lopez Salazar.pdf

Arango, P. (2009). La farsa de las publicaciones universitarias. El Malpensante, 97. Recuperado de http://www. elmalpensante.com/articulo/1031/la_farsa_de_las_publicaciones_universitarias

Arias, N. (2014). En Colombia, un profesor con doctorado puede ganar hasta $\$ 190.000$ por hora. Recuperado de http:// www.larepublica.co/en-colombia-un-profesor-con-doctorado-puede-ganar-hasta-190000-por-hora_179676

Banco Mundial (2012). Gasto en investigación y desarrollo (\% del PIB). Recuperado de http://datos.bancomundial. org/indicador/GB.XPD.RSDV.GD.ZS 
Budapest Open Access Initiative (BOAI) (2012). Ten years on from the Budapest Open Access Initiative: setting the default to open (BOAI10). Italian Journal of Library $\mathcal{G}$ Information Science, 3(2), 1-15. Doi: 10.4403/ jlis.it-8631

Colciencias. (2015). Revistas indexadas - Índice Bibliográfico Nacional - Publindex, 1.a actualización 2014. Rcuperado de http://www.colciencias.gov.co/sites/default/files/ckeditor_files/files/ibnpublindex2014.pdf

El Observatorio de la Universidad Colombiana (2014). Pros y contras de una reforma al Decreto 1279 de 2002. Recuperado de http://www.universidad.edu.co/index.php?option $=$ com_content\&view $=$ article\&id $=530$ 3:pros-y-contras-de-una-reforma-al-decreto-1279-de-2002\&catid=16:noticias\&Itemid =198

Observatorio Colombiano de Ciencia y Tecnología [OCyT]. Indicadores de ciencia y tecnología Colombia 2014. Bogotá: Autor. Recuperado de http://ocyt.org.co/Portals/0/LibrosPDF/OCyT_Indicadores_2014.pdf

Rodríguez, E., Naranjo, S. y González, D. L. (2015). Publindex: más que un proceso de indexación. Ágora U.S.B., 15 (1), 29-41. Recuperado de http://www.scielo.org.co/pdf/agor/v15n1/v15n1a02.pdf 


\section{Editorial}

\section{The future of Economic Sciences journals in Colombia}

http://dx.doi.org/10.14718/revfinanzpolitecon.2015.7.2.1

\section{Joan Miguel Tejedor Estupiñán*}

On the 27th of January 2015, the National Bibliographical Index (IBN Publinex) divulged the list of indexed journals in the first update of 2014. This included 542 scientific publications edited by different institutions, mainly, of higher education, research and development in Colombia. We found 28 journals in categories A1, 138 in A2, 131 in B, and 245 in C (Colciencias, 2015). This is proof of a significant advance in terms of such publications compared to the 515 indexed journals in 2013 or the 91, in 2002, when there was only one journal in category A1, 9 journals in category A2, 7 in category B and 74 in category C (Rodríguez, Naranjo and González, 2015).

The latest Publindex update showed the inclusion 67 journals concerning Colombian economic and administrative sciences - $12.4 \%$ of the total number of national indexed journals - among which 2 were in category A1, 21 in A2, 11 in B and 33 in C. According to the IBN indexing conditions, it seems that particularly journals in categories $A 1$ and $A 2$ are fulfilling most of the requirements established by international peers in relation to the editorial and scientific quality, visibility and impact. In fact, this becomes evident considering that, among these journals; approximately 20 are included in EconLit, 24 in RedALyC, 24 in SciELO, 13 in Scopus and 4 in ISI (Tomson Scientific). Thus, it is clear that just over a third of Colombian production in the economic sciences has reached beyond the national arena, meaning that international visibility and dissemination increases and as such consolidates the recognition of the impact of the articles published.

Part of the importance of this data can be analyzed based on its relationship with different contexts. Moreover, this means that the Colombian scientific community must take responsibility for a number of debates of great importance both for national research and development policies and for the labor policy of the university professors in Colombia, who have a direct relationship with this context.

The first debate falls within the framework of the global position of free access to scientific knowledge (Budapest Open Access Initiative [BOAI], 2012), which, for the past 13 years, has been promoting initiatives of this type that recognize scientific knowledge as a common good and a universal human right (these include proposals such as DOAJ, SciELO and RedALyC). On the other hand, we have international bibliography databases baked by countries belonging to the so-called "mainstream sciences" (where we find ISI-WOS and Scopus, that are recognized among Colombian norms for salary regime of university professors). These databases implement subscription and access fees; they shed light on the scarce participation of Latin American scientific production, and impose restrictions for their

* Masters in Human Rights and Economist. Editor of the journal Revista Finanzas y Política Económica from Universidad Católica de Colombia. E-mail: jmtejedor@ucatolica.edu.co. Mail address: Facultad de Economía, Universidad Católica de Colombia, carrera 13 \# 47-49 (Bogotá, D. C., Colombia). 
access. By doing this they directly discourage the participation of Latin American scientific production and as such limit its visibility and impact (Waterdo and Rogel, 2006).

The second debate rises after the process developed by Publindex in 2012, whose purpose was to establish itself as a national system of reference for the assessment of Colombian scientific publications. The system contributed directly to driving many of the national scientific publications into the international arena. However, it has also been criticized from a number of viewpoints (Arango, 2009). For example, this juncture led Colciencias to decide not to consider Publinex' IBN results, arguing that Decree 1279 of 2002 - which establishes the salary and social security regime of State university professorsin its Article 10 fosters two fundamental problems: The quality of Colombian research and academia has been affected as has the labor market of university professors. This is manifested in the almost insignificant increase in graduate education, which was $9.9 \%$ between 2003 and 2013, compared to an increase of $64.3 \%$ in the scientific productivity of university professors in the same period. In this order of ideas, it is worth highlighting the inequality between the working conditions of university professors in developed countries and developing ones like Colombia. In the latter, a professor can earn between U\$11 and U\$74 per hour (Observatorio de la Universidad Colombiana, 2014), compared to U\$100 per hour that can be the hourly rate for a professor with a PhD in, say, Germany or the U.K. (Arias, 2014).

Finally, one of the most important debates concerns the funds dedicated to the strategic research and development sector (R\&D) in Colombia. The inequality fostered by the terms of competition established by developed nations is evident. In 2012, they invested into the above mentioned sector approximately US\$400.000 million in the United States, US\$300.000 in the European Union, US\$150.000 in China, and US\$130.000 in Japan (World Bank, 2012). In contrast, in Colombia, investment in science, technology and innovation related activities was only just over US\$1.757 million, and investment in R\&D was just over US $\$ 738$ million (Observatorio Colombiano de Ciencia and Tecnología [OCyT], 2014).

This panorama sheds light on the challenges faced by the editorial teams of scientific publications, which take on the responsibility of guaranteeing the top scientific and editorial quality of the journals - from different education and research institutes - that we publish. Thus, in a context whereby science and knowledge are unconnected to the multidimensional process known as globalization, we must set out concerns such as: what should the principles of science and technology R\&D policies Colombia be? Who are the actors that should participate in the construction of such policies? ¿What level of financial, human and physical resources should a country invest in its research and development institutions in order to reach the standards established by developed countries? Which policies and instruments guarantee the effectiveness and efficiency of these resources? These and many other concerns need to be solved politically, by communities that make up the research and development institutions in Colombia in order to guarantee a sustainable future for R\&D.

Aware of this commitment, and of our responsibility of presenting top scientific and editorial quality articles and the impact of their publication, the Revista Finanzas y Política Económica editorial team presents its readers with this new edition in which we seek to publish research papers that are recognized for their high impact. Included in this issue are seven research papers: "The role of financial 
development as a source of economic growth," by José Luis Hernández Mota, Universidad Autónoma Metropolitana-Azcapotzalco, de Mexico; "The cycle of center-periphery dependency in Argentina," by Luciano Rezzoagli and Guillermina Gamberg, Universidad Nacional del Litoral, Santa Fe, Argentina; "Water resource management and economic value," by William Gilberto Delgado Munevar, Universidad Católica de Colombia; followed by "The role of the sub-national public sector in the stabilization function: Evidence from the Colombian case in the 1990-2000 period," written by Ligia Melo Becerra, Banco de la República de Colombia; "Why does Colombia lack agricultural commodity futures?" by Pablo Moreno Alemay and Catherine Pereira Villa, Universidad de La Sabana, Colombia; "Comparative efficiency analysis: Brazil, Mexico and The United States," written by Juan Benjamín Duarte Duarte, Katherine Julieth Sierra Suárez and Víctor Alfonso Rueda Ortiz, Universidad Industrial de Santander, Colombia; and to end this section, the article "Determining factors of the capital structure of MSMEs in the real sector that took part in the Colombian Innova Prize 2007-2011," by Ana Milena Padilla Ospina, Jorge Alberto Rivera Godoy and Javier Humberto Ospina Holguín, Universidad del Valle, Colombia. Finally, we have the review article "Monetary policy positions in the face of economic fluctuations: A review of the theoretical evolution," by José Mauricio Gil León, Universidad Pedagógica y Tecnológica de Colombia.

\section{REFERENCES}

Aguado López, E. and Rogel Salazar, R. (2006). Redalyc: Red de Revistas Científicas de América Latina, el Caribe, España y Portugal. Un balance a tres años de camino. In D. Babini and J. Fraga (Eds.), CLACSO, Consejo Latinoamericano de Ciencias Sociales (pp. 209-233). Buenos Aires: CLACSO. Recovered from http:// bibliotecavirtual.clacso.org.ar/ar/libros/secret/babini/Waterdo Lopez Salazar.pdf

Arango, P. (2009). La farsa de las publicaciones universitarias. El Malpensante, 97. Recovered from http://www. elmalpensante.com/articulo/1031/la_farsa_de_las_publicaciones_universitarias

Arias, N. (2014). En Colombia, un profesor con doctorado puede ganar hasta $\$ 190.000$ por hora. Recovered from http:// www.larepublica.co/en-colombia-un-profesor-con-doctorado-puede-ganar-hasta-190000-por-hora_179676

Budapest Open Access Initiative (BOAI) (2012). Ten years on from the Budapest Open Access Initiative: setting the default to open (BOAI10). Italian Journal of Library $\mathcal{F}$ Information Science, 3(2), 1-15. Doi: 10.4403/ jlis.it-8631

Colciencias. (2015). Journals indexadas - Índice Bibliográfico Nacional - Publindex, 1. a actualización 2014. Recovered from http://www.colciencias.gov.co/sites/default/files/ckeditor_files/files/ibnpublindex2014.pdf

El Observatorio de la Universidad Colombiana (2014). Pros y contras de una reforma al Decreto 1279 de 2002. Recovered from http://www.universidad.edu.co/index.php?option $=$ com_content\&view $=$ article\&id $=53$ 03:pros-y-contras-de-una-reforma-al-decreto-1279-de-2002\&catid=16:noticias\&Itemid = 198

Observatorio Colombiano de Ciencia y Tecnología [OCyT]. Indicadores de ciencia y tecnología Colombia 2014. Bogotá: Autor. Recovered from http://ocyt.org.co/Portals/0/LibrosPDF/OCyT_Indicadores_2014.pdf 
Rodríguez, E., Naranjo, S. and González, D. L. (2015). Publindex: más que un proceso de indexación. Ágora U.S.B., 15(1), 29-41. Recovered from http://www.scielo.org.co/pdf/agor/v15n1/v15n1a02.pdfhttp://dx.doi. org/10.14718/revfinanzpolitecon.2015.7.1.1

World Bank (2012). Gasto en investigación and desarrollo (\% del PIB). Recovered from http://datos.bancomundial. org/indicador/GB.XPD.RSDV.GD.ZS 


\section{Editorial}

\section{O futuro das revistas de ciências econômicas na Colômbia}

http://dx.doi.org/10.14718/revfinanzpolitecon.2015.7.2.1

\section{Joan Miguel Tejedor Estupiñán*}

Em 27 de janeiro de 2015, o Índice Bibliográfico Nacional (IBN Publindex) divulgou a lista de revistas indexadas na primeira atualização de 2014, na qual que se reconhecem 542 publicações científicas editadas por diferentes instituições, em sua maioria de educação superior, pesquisa e desenvolvimento na Colômbia. Encontramos nela 28 revistas na categoria A1, 138 na A2, 131 na B e 245 na C (Colciencias, 2015), o que representa o avanço significativo dessas publicações em comparação com as 515 revistas indexadas em 2013, e muito mais se o compararmos com as 91 revistas indexadas em 2002, quando apenas uma revista estava na categoria A1, 9 revistas na $A 2,7$ na B e 74 na $C$ (Rodríguez, Naranjo e González, 2015).

Na última atualização do Publindex foram reconhecidas 67 revistas relacionadas com as ciências econômicas e administrativas colombianas - $12,4 \%$ do total de revistas indexadas nacionais - dentro das quais, duas se posicionaram na categoria $A 1,21$ na $A 2,11$ na $B$ e 33 na $C$. Segundo as condições de indexação do IBN, em especial as revistas que se encontram nas categorias A1 e A2 estariam cumprindo com a maioria dos requisitos estabelecidos por pares internacionais a respeito da qualidade editorial, qualidade científica, visibilidade e impacto. De fato, isso é evidenciado quando constatamos que, dessas revistas, aproximadamente 20 se encontram no EconLit, 24 no RedALyC, 24 no SciELO, 13 no Scopus e 4 no ISI (Tomson Scientific). Fica claro, portanto, que pouco mais de um terço da produção colombiana em ciências econômicas ultrapassou a fronteira nacional e, com isso, aumentou-se a visibilidade e a divulgação internacional, além de consolidar processos de reconhecimento do impacto dos documentos que nelas são publicados.

Parte da importância desses dados pode ser analisada a partir de sua relação com diferentes contextos. Além disso, deve levar a comunidade científica nacional a assumir vários debates de grande transcendência tanto para a política nacional de pesquisa e desenvolvimento quanto para a política coorporativa dos docentes universitários na Colômbia, que têm uma direta relação com esse contexto.

O primeiro debate acontece no âmbito da postura mundial do acesso aberto ao conhecimento científico (Budapest Open Access Initiative [BOAI], 2012), que existe há mais de 13 anos e promove iniciativas desse tipo que legitimam o conhecimento científico como um bem comum ou um direito humano universal (estão presentes nela DOAJ, SciELO e RedALyC). Por outro lado, encontramos as bases bibliográficas internacionais impulsionadas pelos países da chamada "grande corrente da ciência"

* Mestre em Direitos Humanos e Economista. Editor da Revista Finanzas y Política Económica de la Universidad Católica de Colombia. E-mail: jmtejedor@ucatólica.edu.co. Endereço para correspondência: Facultad de Ciencias Económicas y Administrativas, Universidad Católica de Colombia, carrera 13 \# 47-49 (Bogotá, D. C., Colombia).. 
(na qual encontramos o ISI-WOS e o Scopus, que são reconhecidos nas normatividades nacionais para conceitos do regime salarial dos docentes universitários). Estes últimos bancos de dados cobram pela assinatura e pelo acesso aos conteúdos e, além disso, demonstram a escassa participação da produção científica latino-americana e impõem restrições para seu acesso a essas bases bibliográficas; com isso, afastam de maneira direta a participação da produção científica latino-americana dessa corrente e limitam da mesma maneira sua visibilidade e impacto (Aguado e Rogel, 2006).

O segundo debate surge depois do processo desenvolvido pelo Publindex de 2012 até a atualidade, cujo propósito era ser consolidado como o sistema nacional de referência para a avaliação de publicações científicas colombianas. Esse sistema tem contribuído de maneira direta na promoção de grande parte das publicações científicas nacionais no âmbito internacional; contudo, não é alheio às críticas de diferentes perspectivas (Arango, 2009). Essa conjuntura conduziu, por exemplo, a que, para a última medição de grupos, o Colciencias decidisse não considerar os resultados do IBN do Publindex; argumentou que o Decreto 1.279 de 2002, artigo 10, pelo qual é estabelecido o regime salarial e de prestação de serviços dos docentes das universidades do Estado, tem gerado dois problemas fundamentais: tem afetado a qualidade da pesquisa e da academia na Colômbia, bem como o mercado de trabalho dos docentes universitários. Estes manifestam o aumento pouco significativo da formação pós-graduada, que foi de 9,9\% entre 2003 e 2013, ante o aumento de $64,3 \%$ da produtividade científica dos docentes universitários durante o mesmo período.

Nesse sentido, cabe salientar a desigualdade entre as relações de trabalho dos docentes universitários dos países desenvolvidos em relação aos países em via de desenvolvimento, como a Colômbia, onde um docente pode ganhar por hora entre USD\$11 e USD\$74 (El Observatorio de la Universidad Colombiana, 2014), comparados aos USD $\$ 100$ por hora que pode ganhar um docente com doutorado em países como a Alemanha e o Reino Unido (Arias, 2014).

Finalmente, um dos debates mais importantes se refere aos recursos econômicos destinados no âmbito nacional para o setor estratégico de pesquisa e desenvolvimento $(P+D)$. Há uma evidente desigualdade nos termos de concorrência gerados pelas nações desenvolvidas, as quais até 2012 investiam no setor em torno de USD $\$ 400$ bilhões de dólares nos Estados Unidos, USD $\$ 300$ bilhões na União Europeia, USD\$150 bilhões na China e USD\$130 bilhões no Japão (Banco Mundial, 2012). Em contrapartida, na Colômbia, o investimento em atividades de ciências, tecnologia e inovação está em torno de USD $\$ 1,7$ bilhões, e o investimento em $\mathrm{P}+\mathrm{D}$ mal passa dos USD $\$ 738$ milhões (Observatorio Colombiano de Ciencia y Tecnología [OCyT], 2014).

Esse panorama reflete os diferentes desafios que hoje, mais do que nunca, as equipes editoriais das publicações científicas devem empreender, as quais assumem garantir a alta qualidade científica e editorial das revistas que lideram dentro das instituições que as apoiam. Assim, num contexto em que a ciência e o conhecimento não são alheios ao processo multidimensional chamado no jargão atual de globalização, devemos apresentar questionamentos como estes: quem são os atores que devem participar da construção dessas políticas? Qual é o nível de recursos econômicos, humanos e físicos que um país e suas instituições de pesquisa e desenvolvimento devem investir a fim de atingir os padrões dos países 
desenvolvidos nesse setor? Quais são as políticas e os instrumentos que garantiriam a efetividade e a eficiência desses recursos? Estes e muitos outros questionamentos são chamados a serem respondidos de maneira política por comunidades que conformam as instituições de pesquisa e desenvolvimento na Colômbia para garantir um futuro sustentável para a P+D na Colômbia.

Conscientes desse compromisso e da nossa responsabilidade pela qualidade científica e editorial e pelo impacto das pesquisas que publicamos, a equipe editorial da Revista Finanzas y Política Económica apresenta a seus leitores esta nova edição, na qual buscamos publicar pesquisas reconhecidas por seu alto impacto. Encontramos, portanto, sete artigos de pesquisa: "O papel do desenvolvimento financeiro como fonte do crescimento econômico", de José Luis Hernández Mota, da Universidad Autónoma Metropolitana-Azcapotzalco, do México; em seguida, "O ciclo de dependência centro-periferia na Argentina", de Luciano Rezzoagli e Guillermina Gamberg, da Universidad Nacional del Litoral, de Santa Fe, Argentina; depois, o artigo "Gestão e valor econômico do recurso hídrico", de William Gilberto Delgado Munevar, da Universidad Católica de olombia; mais adiante, "O papel do setor público subnacional na função de estabilização: evidência do caso colombiano no período de 1990-2000", escrito por Ligia Melo Becerra, do Banco da República da Colômbia; continuamos com o "Why does Colombia lack agricultural commodity futures?", de Pablo Moreno Alemay e Catherine Pereira Villa, da Universidad de La Sabana, Colômbia; na sequência, "Análise comparativa de eficiência entre Brasil, México e Estados Unidos", escrito por Juan Benjamín Duarte Duarte, Katherine Julieth Sierra Suárez e Víctor Alfonso Rueda Ortiz, da Universidad Industrial de Santander, Colômbia; para finalizar esta seção, o texto "Determinantes da estrutura de capital das micro e pequenas empresas do setor real participantes do prêmio Innova 20072011", de Ana Milena Padilla Ospina, Jorge Alberto Rivera Godoy e Javier Humberto Ospina Holguín, da Universidad del Valle, Colômbia. Finalmente, encontramos o artigo de revisão intitulado "Posturas de política monetária ante flutuações da economia: uma revisão da evolução teórica", de José Mauricio Gil León, da Universidad Pedagógica y Tecnológica de Colombia.

\section{REFERÊNCIAS}

Aguado López, E. e Rogel Salazar, R. (2006). Redalyc: Red de Revistas Científicas de América Latina, el Caribe, España y Portugal. Un balance a tres años de camino. Em D. Babini e J. Fraga (Eds.), CLACSO, Consejo Latinoamericano de Ciencias Sociales (pp. 209-233). Buenos Aires: CLACSO. Disponível em http://bibliotecavirtual.clacso.org.ar/ar/libros/secret/babini/Aguado Lopez Salazar.pdf

Arango, P. (2009). La farsa de las publicaciones universitarias. El Malpensante, 97. Disponível em http://www. elmalpensante.com/articulo/1031/la_farsa_de_las_publicaciones_universitarias

Arias, N. (2014). En Colombia, un profesor con doctorado puede ganar hasta $\$ 190.000$ por hora. Disponível em http:// www.larepublica.co/en-colombia-un-profesor-con-doctorado-puede-ganar-hasta-190000-por-hora_179676

Banco Mundial (2012). Gasto en investigación y desarrollo (\% del PIB). Disponível em http://datos.bancomundial. org/indicador/GB.XPD.RSDV.GD.ZS

Budapest Open Access Initiative (BOAI) (2012). Ten years on from the Budapest Open Access Initiative: setting 
the default to open (BOAI10). Italian Journal of Library $\mathcal{E}$ Information Science, 3(2), 1-15. Doi: 10.4403/ jlis.it-8631

Colciencias. (2015). Revistas indexadas — Índice Bibliográfico Nacional — Publindex, 1ªctualización 2014. Disponível em http://www.colciencias.gov.co/sites/default/files/ckeditor_files/files/ibnpublindex2014.pdf

El Observatorio de la Universidad Colombiana (2014). Pros y contras de una reforma al Decreto 1279 de 2002. Disponível em http://www.universidad.edu.co/index.php?option $=$ com_content\&view $=$ article\&id $=530$ 3:pros-y-contras-de-una-reforma-al-decreto-1279-de-2002\&catid=16:noticias\&Itemid =198

Observatorio Colombiano de Ciencia y Tecnología [OCyT]. Indicadores de ciencia y tecnología Colombia 2014. Bogotá: Autor. Disponível em http://ocyt.org.co/Portals///LibrosPDF/OCyT_Indicadores_2014.pdf

Rodríguez, E., Naranjo, S. e González, D. L. (2015). Publindex: más que un proceso de indexación. Ágora U.S.B., 15 (1), 29-41. Disponível em http://www.scielo.org.co/pdf/agor/v15n1/v15n1a02.pdf 